\title{
Long-Term Outcomes of Percutaneous Retrogasserian Glycerol Rhizotomy in 3370 Patients with Trigeminal Neuralgia
}

\author{
Trigeminal Nöraljisi Olan 3370 Hastada Retrogaserian Gliserol \\ Riztomisinin Geç Dönem Sonuçları
}

Wang XU-HUI, Zhou CHUN, Shen GUANG-JIAN, Xu MIN-HUI, Chen GUANG-XIN, Zou YONG-WEN, $\mathrm{Xu}$ LUN-SHAN

Research Institute of Surgery \& Daping Hospital, Third Military Medical University, Department of Neurosurgery, Chongqing, China

Correspondence address: Xu LUN-SHAN / E-mail: kevin6811@yeah.net

\begin{abstract}
AIM: To assess the long-term outcomes of percutaneous retrogasserian glycerol rhizotomy (PRGR) in patients with medically unresponsive idiopathic trigeminal neuralgia.

MATERIAL and METHODS: A total of 3370 patients undergoing PRGR between 1983 and 2003 in our hospital were followed up for 13.1 years (range 3-23 years), and the outcomes were investigated.

RESULTS: Of the 3370 patients, $99.58 \%$ had complete initial pain relief. A total of 2750 patients were followed up when 112 died of unrelated causes and 508 were lost to follow up. Of the 2750 patients, 962 (35\%) had pain recurrence at various intervals: $0.3 \%$ in 1 year; $21 \%$ in 1 to 5 years; $7 \%$ in 5 to 10 years; $4 \%$ in 10 to 15 years and $3 \%$ in 15 to 23 years. The major complication was facial numbness, among which hypesthesia outweighed hypalgesia. Most patients recovered within half a year, although 109 patients (3.96\%) developed permanent mild hypesthesia. There was no anesthesia dolorosa or surgery related mortality in this series.

CONCLUSION: PRGR is a minimally invasive and simple procedure yielding a favorable outcome for trigeminal neuralgia. The major complications of this procedure are reversible within various time intervals. It may serve as a first-line surgical modality for patients unresponsive to pharmacotherapy.
\end{abstract}

KEYWORDS: Trigeminal neuralgia, Percutaneous retrogasserian glycerol rhizotomy, Hypesthesia, Recurrence

öz

AMAÇ: Tıbbi tedaviye cevap vermeyen Trigeminal nöraljili hastalarda perkütan yol ile yapılan retrogasserian gliserol rizotomisinin (RGGR) uzun dönemli sonuçlarının değerlendirilmesi.

YÖNTEM ve GEREÇ: 1983-2003 yılları arasında RGGR yapılan 3370 hasta ortalama 13,1 yıl takip edildi (3-23 yıl) ve bu hastaların klinik sonuçları incelendi.

BULGULAR: Başlangıçta 3370 hastanın \% 99.58'de ağrıda azalma meydana geldi. Takibi yapılan 2750 hastadan 112 'si klinik takip sırasında Trigeminal nöralji ve tedavisi dışı nedenlerden öldü. Hastalardan 508'i ise takiplere gelmedi. Toplam 2750 hastadan 962'sinde (\%35) ağrı değişik zamanlarda tekrar ortaya çıktı. Hastaların \%0,3'ünde ağrı ilk yılın içinde, \% 21'inde 1-5 yıl içinde, \%7sinde 5-10 yıl içinde, \%4'ünde 10-15 yıl içinde ve \%3'ünde 15-23 yıl içinde ağrı yeniden oluştu. En sık rastlanan yan etkiler yüzde hissizlik yakınmasıydı ve bu yakınmalar daha çok hipoestezi tarzında olan yakınmalardı. Bu hastaların önemli bir kısmında bu yakınmalar 6 ay içerisinde düzeldi, ancak 109 hastada (\%3,96) kalıcı hipoestezi oluştu. Bu seride, yapılan girişime anesthesia dolorosa ve herhangi bir mortalite oluşmamıştır.

SONUÇ: RGGR işlemi, minimal invaziv yolla yapılan ve Trigeminal nöraljili hastalarda iyi klinik cevap alınan bir yöntemdir. Bu işleme bağlı olarak görülen en önemli komplikasyonlar değişik zaman dilimleri içerisinde düzelme göstermektedir. Bu yöntem tıbbi tedaviye cevap vermeyen Trigeminal nöraljili hastalar için uygulanacak 1. cerrahi seçenektir.

ANAHTAR SÖZCÜKLER: Trigeminal nöralji, Retrogasserian gliserol rizotomisi, Hypestesia, Rekürens

\section{INTRODUCTION}

A total of 3370 patients with medically unresponsive idiopathic trigeminal neuralgia undergoing percutaneous retrogasserian glycerol rhizotomy (PRGR) between 1983 and
2003 in our hospital were retrospectively analyzed in the present study. High rates of complete initial pain relief and good recovery of facial hypesthesia were observed during the long-term follow-up. Although trigeminal neuralgia may recur, PRGR remains the treatment of choice for trigeminal 
neuralgia patients unresponsive to pharmacological intervention. The results of the study are reported as follows.

\section{MATERIAL and METHODS}

\section{Clinical data}

There were 1273 men and 2097 women, with a mean age of 61.3 years (range: $34-90$ years), including 1286 patients aged between 60 and 70 years, 1409 patients aged between 70 and 80 years, and 191 patients aged 80 years or older. The course of disease ranged from 3 months to 31 years, with a mean course of 3.74 years. Trigeminal neuralgia affected the right side in 1895 cases, the left side in 1459 cases, and both sides in 16 cases (including 7 cases with disseminated sclerosis). In addition, 368 patients had pain in branches I, II, III, 1048 in branches II and III, 404 in branches I and II, 89 in branch I, 679 in branch II, and 782 in branch III. Concomitant hypertension or coronary artery disease or other diseases were found in 136 patients. Patients with a coagulation disorder were excluded. All patients took long-term carbamazepine. Once the therapeutic effect tapered off or a side effect that could not be tolerated appeared, peripheral branch rhizotomy was performed in 310 cases, avulsion in 69 cases, trigeminal ganglion radiofrequency thermocoagulation in 36 cases, gamma knife surgery in 198 cases and microvascular decompression (MVD) in 11 cases. All patients underwent computed tomography (CT) or magnetic resonance imaging (MRI) scans before conventional therapy after 1990. The $99 \%$ medical glycerol was purchased from Wuhan Galaxy Chemical Co., Ltd., sterilized in an autoclave and stored in a $2 \mathrm{ml}$ sealed bottle for use.

\section{Treatments}

In addition to a conventional explanation of the treatment procedure and the possible discomforts to the patients, oral diazepam was administered $30 \mathrm{~min}$ before the operation. The Backlying-Hakanson anterior approach puncture was adopted.

A supine position with $10 \sim 20^{\circ}$ of head back extension was maintained during puncturing (Figure 1). The puncture instrument was retrieved while local anesthesia was administered to avoid pricking into the mouth. Puncture was performed with a No. 9 lumbar puncture needle, which reached the middle basalis, and puncture direction was adjusted according to the feeling from the needle tip. When the needle touched the middle basalis and punctured the foramen ovale, there was an obvious feeling of lack of resistance. Most of patients had episodic pain. The needle further entered 1 1.5 $\mathrm{cm}$ in depth and reached the Meckel cyst. Then $0.2 \mathrm{ml}$ of $2 \%$ procaine was injected to test the rhizotomy region. The episode region was anesthetized and the algesthesis on the related facial region completely disappeared while puncturing, which confirmed the correctness of needle tip location. Then $0.3 \sim 0.5 \mathrm{ml}$ anhydrous-glycerol was injected. During the injection, the position of patient and head was maintained for patients without cerebrospinal fluid flow. A sitting position is preferable for patients with cerebrospinal fluid flow to avoid

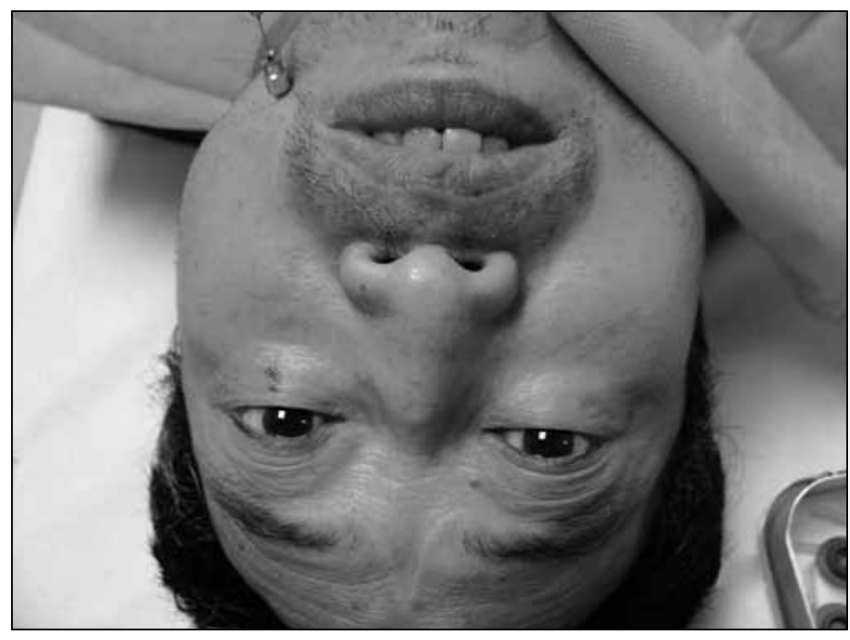

Figure 1: Position of the patient and head during puncturing.

the entry of glycerol into subarachnoid space. After retrieving the transfixion pin, part of the transfixion pin was pressed on with a thumb for 5 min to avoid hematoma. Then, the head of transfixion pin was kept in an anteversion position to prevent glycerol diffusion to the cavitas subarachnoidealis. A sitting position was maintained after injection. $30 \sim 80^{\circ}$ of head anteversion is suggested based on the pain site. $30 \sim 40^{\circ}$ of head anteversion is preferable for patients with trigeminal neuralgia affecting branch III and $30 \sim 40^{\circ}$ of head anteversion for branch I. The position of the head was maintained for at least $1 \mathrm{~h}$. The treatment was performed again if pain was not relieved within a short period ( 3 days) after the therapy, until complete pain relief was achieved. Patients with recurrence received $P R G R$ in an out-patient clinic.

\section{RESULTS}

\section{Initial pain relief}

A total of 2469 patients had complete initial pain relief after one glycerol rhizotomy and 2421 had persistently episodic numbness. Irresponsive patients showed a quick disappearance of facial numbness. These patients were accepted to have ineffective treatment and needed the second operation. In addition, 637 patients had complete pain relief after the second rhizotomy and 215 had major pain relief after the third rhizotomy. Only 4 patients underwent the fourth rhizotomy. No patients had rhizotomy more than four times. Nine cases were irresponsive to foramen ovale puncture with hand and received puncture under the perspective. Fourteen patients had an unsatisfactory result after 2 3 rhizotomies and received other therapies. The total rate of effectiveness was $99.58 \%$ (Table I). No surgery-related mortality occurred.

The results showed that the pain relief had the characteristics of all or none in these patients. Some patients felt themselves relieved but had recurrence after follow-up for several days, considered as ineffective treatment. A second rhizotomy was performed for patients with recurrence. 


\section{Major complications and corresponding treatments}

One patient was punctured in the fissura orbitalis inferior by mistake, causing optic nerve injury, and 5 patients had arterial hemorrhage. After inserting the needle tip and then withdrawing the needle gradually to stop bleeding, no continued damage appeared. One case had infection in the puncturing location which complicated the facial hypesthesia and resulted in the facial formation after recovery. Two cases had trigeminal motor weakness, 12 had mydriasis after procaine test due to deep puncture. After withdrawing the needle a little bit, the glycerol rhizotomy was continued. In addition, 325 had nausea and vomiting after glycerol injection. A total of 3298 cases (98\%) had transient facial hypesthesia, facial sensory deprivation or anesthesia dolorosa (Table II). The facial hypesthesia was not selective and included the compromised sense of touch and algesthesis. Cases where hypesthesia outweighed hypalgesia needed non-specific treatment. Those who had trigeminal neuralgia in branch I required ocular region care and regular ophthalmology clinic visits.

\section{Follow-up}

Conventional follow-up was conducted to observe the recovery of facial hypesthesia within 6 months. A total of 2750 cases completed the follow-up: 112 died of senility and other internal diseases, and 508 were lost to follow up, most of which occurred before 1990. Forty two had ocular complaints, 6 keratitis ulcer, and 1 acroisa due to ulcer. These patients had facial anesthesia, without anesthesia dolorosa, severe hypesthesia or anesthesia. The facial anesthesia gradually decreased. Most of the patients recovered within half a year while some still had low grade hypesthesia (109/2750) which was acceptable and did not affect the daily life (Table II). There were few recurrences within 1 year. Three cases recurred immediately after the recovery of facial hypesthesia, Four cases recurred several months after the recovery of facial hypesthesia. Most of the recurrences occurred during the second to the fifth year (Table III).

\section{DISCUSSION}

Trigeminal neuralgia is the most common cause of neurosurgical tortua facies, the incidence of which increases over time with the social development. The characteristics of trigeminal neuralgia is episodicity, lightning and strict localization in the trigeminal nerve region which distinguish it from other tortua facies. It can be provoked spontaneously or by the trigger point. The diagnosis of trigeminal neuralgia can be confirmed by the efficacy of carbamazepine but carbamazepine may be generally ineffective or some patients probably cannot tolerate its side effects and need surgical treatment. Treatment methods of trigeminal neuralgia included peripheral branch rhizotomy, avulsion,

Table I: Relationship between Glycerol Rhizotomy Times and Pain Relief

\begin{tabular}{|c|c|c|c|c|c|c|}
\hline Rhizotomy & First & Second & Third & Fourth & Puncture under perspective & Total \\
\hline Pain Relief (n) & 2479 & 647 & 217 & 4 & 9 & 3356 \\
\hline Rate (\%) & $73.56 \%$ & $19.20 \%$ & $6.44 \%$ & $0.12 \%$ & $0.26 \%$ & $99.58 \%$ \\
\hline
\end{tabular}

Table II: Short- and Long-Term Complications after Percutaneous Retrogasserian Glycerol Rhizotomy

\begin{tabular}{|c|c|c|c|c|c|}
\hline \multicolumn{3}{|c|}{ Short Time } & \multicolumn{3}{|c|}{6 Months } \\
\hline Transient facial hypesthesia & 3298 & $97.86 \%$ & Low grade hypesthesia & 109 & $3.96 \%$ \\
\hline Nausea/Vomiting & 325 & $9.64 \%$ & Ocular complaint & 42 & $1.53 \%$ \\
\hline Corectasis & 12 & $0.36 \%$ & Keratitis ulcer & 6 & $0.22 \%$ \\
\hline Trigeminal motor weakness & 2 & $0.06 \%$ & Acroisa & 1 & $0.04 \%$ \\
\hline Infection & 1 & $0.03 \%$ & & & \\
\hline Hemorrhage & 5 & $0.15 \%$ & & & \\
\hline Optic nerve injury & 1 & $0.03 \%$ & & & \\
\hline
\end{tabular}

Table III: Time-Related Recurrence Rate

\begin{tabular}{|l|c|c|c|c|c|c|c|}
\multicolumn{1}{c|}{ Years } & 1 & $1-5$ & $5-10$ & $10-15$ & \multicolumn{2}{c|}{ Total } \\
\hline Recurrence $(\mathrm{n})$ & 8 & 577 & 193 & 110 & 82 & 962 \\
\hline Rate $(\%)$ & $0.3 \%$ & $21 \%$ & $7 \%$ & $4 \%$ & $3 \%$ & $35 \%$ \\
\hline
\end{tabular}


radiofrequency of the semilunar ganglion, retrogasserian glycerol ectomy, semilunar ganglion sacculus proprius compression, retrogasserian ectomy or carding manipulation, microvascular decompression and gamma knife surgery. With the generalization of the microvascular decompression, many investigators agree with the retrogasserian vascular compression theory. Trigeminal vascular compression has been observed in most of patients with trigeminal neuralgia during the operation. The symptoms disappeared after putting teflon pad, with the efficacy rate of greater than $92.7 \%$, mortality rate of $0.7 \%$, and median time to relapse of 1.9 years. About $47 \sim 75 \%$ of recurrences occurs within 1 year after operation. The recurrence rate is about $2 \%$ annually, and there are some operation complications (1). The surgery is simple and effective, and there was no age limit in treating trigeminal neuralgia with retrogasserian glycerol rhizotomy. Being a convenient, economic and effective strategy to treat trigeminal neuralgia, retrogasserian glycerol rhizotomy can be applied in a lot of diseases in some developing countries like China.

The therapeutic mechanism of PRGR is still unclear. Study indicates that absolute ethanol has destructive effects on both thin non-myelinated fibers and myelinated fibers, which may be more obvious in fat myelinated fibers $(2,6)$. For patients with clear trigger point, haptics conducted through the fat myelinated fibers may provoke the episodic pain. We propose that the destructive effects of glycerol made the short circuit effect disappear and cure. Patients with clear trigger point are therefore candidates. Our results showed the efficacy was not selective. Most of patients with disappearance of episodic pain had concomitant facial hypesthesia, but the pain didn't recur when hypesthesia resolved. Therefore, the pain could be relieved without nerve root decompression and would not relapse within a long period. The study indicated the efficacy of retrogasserian glycerol rhizotomy was probably related to the remyelinization of demyelinated neurofibers (11), contributing to the repair of neurofibers.

The key factors involved in the therapeutic effects of PRGR are foramen ovale puncture and the individuated rhizotomy regions. Orientation technology or navigation can achieve successful pricking (9), but surgery needs special and expensive equipment. The precise anatomical localization has been an assurance of pricking by hand (10). With the proficiency of pricking technology, the individuated rhizotomy regions have been an absolute factor impacting the therapeutic effects. It has been reported that the cerebrospinal fluid is an indicating factor $(4,12)$. That injection of procaine to test facial hypesthesia while the cerebrospinal fluid leaks may achieve a complete pain relief (12), and this procedure is also effective in some patients without cerebrospinal fluid leakage. This may be related to the distribution of "pathological" fibers in the nerve roots. When the pathological fibers are in the periphery, they are soaked in the cerebrospinal fluid so that the glycerol can generate the efficacy. When the pathological fibers are in the interior, they could not drain the cerebrospinal fluid. The key factor related to the efficacy is the procaine test with a small amount of procaine. Keeping the position of the transfixion pin while facial hypesthesia appears and then injection of the glycerol are the assurance of favorable therapeutic effects. Other findings show that injection of corresponding amount of glycerol according to the volume of the Meckel cyst measured by opacification can reduce the side effects (7). According to our experience, the conventional dosage of glycerol was $0.3 \mathrm{ml}$, and did not exceed $0.5 \mathrm{ml}$, with most patients with facial hypesthesia recovering during the clinical follow-up.

Hemorrhage is a complication affecting further operations. Hemorrhage during the pricking occurs mainly in the facial buccinator muscles, veniplex near the foramen ovale and by arterial spurting at the puncture site. Our results indicated that hemorrhage could be avoided by the following procedures: 1) To adjust pricking direction when anesthesia and avoid multiple pricking; 2 ) To use the middle basalis sclerotin as a reference while pricking foramen ovale and touch the sclerotin to know the depth of pricking. 3) Treatment of hemorrhage: arterial hemorrhage can sometimes be avoided while venous hemorrhage is inevitable. Venous blood emerging from the transfixion pin may interfere with the operation and might cause serious complications affecting the efficacy in the present study. When the middle skull base serves as a reference and venous blood emerges while pricking near the foramen ovale, the needle should be forwarded several millimeters or withdrawn from the foramen ovale to the periphery sclerotin and the puncture performed again. Arterial hemorrhage is sometimes a result of damage to the middle meningeal artery and the internal carotid artery and can be in a spurting manner. To insert and withdraw the needle gently may avoid serious complications. Being familiar with the anatomic structure around the foramen ovale can prevent injury of the internal carotid artery (10).

The hypesthesia after retrogasserian glycerol rhizotomy may mostly recover within half a year. However, during the recovery period, the patients with pain in branch I or with hypesthesia in the branch I after rhizotomy should inform the ophthalmology nurses or visit the ophthalmology department as soon as possible to prevent against keratohelcosis and other complications. A few patients continue to have low grade hypesthesia which is acceptable and does not affect the daily life. The possible mechanism involving in the different prognoses of hypesthesia may be that the essence of retrogasserian glycerol rhizotomy is the damage to axon. The site of glycerol rhizotomy is near or in the semilunar ganglion neurons, or over-injection of glycerol damages the semilunar ganglion neuron which may be the etiological factors resulting in incomplete recovery of hypesthesia. Clinically, injection of a large amount of glycerol is not recommended, and additionally neuron rhizotomy in the semilunar ganglion should be avoided.

Our results from long-term follow-up suggested that the time intervals of the recurrence were varied. The total recurrence rate was $35 \%$. Few cases had recurrence within 5 years, and 
occurrence can not present in 20 years in some of patients. The patients with recurrence have tendency to recur, but the time to effectiveness is not shorter over time. A second rhizotomy may be effective for all the patients with recurrence, and so it is feasible to perform retrogasserian glycerol rhizotomy in senile patients. The mechanism of recurrence can be explained: since the changes in the demyelination locating between Schwann cells and oligodendrocytes are the pathological basis of trigeminal neuralgia, the trigeminal neuralgia is induced by vessel compression or changes in the demyelination caused by other factors. Glycerol rhizotomy produces the re-formation of myelin and subsequent cure. When the causative factors present and the pathological basis appears, recurrence is unavoidable and this should be confirmed in further studies.

The results of glycerol injection (GI) and radiofrequency thermocoagulation (RF) were similar to those of microvascular decompression (MVD). Although the proportion of patients with remission of the pain immediately after surgery was small, but the 3 -year success rate was $54.8 \%$ in patients who underwent $\mathrm{Gl}$ and $70.7 \%$ in patients who underwent percutaneous RF. In contrast, $85.6 \%$ of patients who underwent MVD remained pain-free 3 years later (3). Except for facial sensory disturbance, the complication rate following $\mathrm{Gl}$ or RF was relatively low without deaths (5). Patients undergoing MVD had no facial sensory disturbance and therefore, MVD is suitable for patients with long life expectancy and having high expectation for the quality of life but MVD can lead to mortality and infection to a certain extent. Furthermore, the Gl-induced facial sensory disturbance is largely reversible, which is different from that caused by RF (8).

To date, there has been no simple and standard strategy for the refractory trigeminal neuralgia. The individualized preference should be adopted according to the practical situation. PRGR is a simple and effective therapeutic strategy for trigeminal neuralgia and the nerve lesion is reversible. It is applicable to senile patients and those unsuitable for operation. It can also be an option for young patients unresponsive to pharmacotherapy. If it recurs within a short period, microvascular decompression is recommended as soon as possible. A second retrogasserian glycerol rhizotomy is preferable for senile patients with recurrence.

\section{REFERENCES}

1. Apfelbaum Rl: Advantages and disadvantages of various techniques to treat trigeminal neuralgia. In Rovit RL, Murali R, Jannetta PJ(eds) Trigeminal Neuralgia. Baltimore: Williams \& Wilkins, 239-250, 1990

2. Eide $P K$, Rabben $T$, Skjelbred $P$, et al: The effect of peripheral glycerol on trigeminal neuropathic pain examined by quantitative assessment of abnormal pain and sensory perception. Acta Neurochir (Wien) 140(12):1271-1277, 1998

3. Haridas A, Mathewson C, Eljamel S: Long-term results of 405 refractory trigeminal neuralgia surgeries in 256 patients. Zentralbl Neurochir 69(4): 170-174, 2008

4. Jagia $M$, Bithal $P K$, Dash $H H$, Prabhakar $H$, Chaturvedi $A$ Chouhan RS: Effect of cerebrospinal fluid return on success rate of percutaneous retrogasserian glycerol rhizotomy. Reg Anesth Pain Med 29(6):592-595, 2004

5. Obermann $M$, Katsarava Z: Update on trigeminal neuralgia. Expert Rev Neurother 9(3): 323-329, 2009

6. Pickett GE, Bisnaire D, Ferguson GG: Percutaneous retrogasserian glycerol rhizotomy in the treatment of tic douloureux associated with multiple sclerosis. Neurosurgery 56(3):537-545, 2005

7. Pollock BE: Percutaneous retrogasserian glycerol rhizotomy for patients with idiopathic trigeminal neuralgia: A prospective analysis of factors related to pain relief. J Neurosurg 102(2): 223-228, 2005

8. Spatz AL, Zakrzewska JM, Kay EJ: Decision analysis of medical and surgical treatments for trigeminal neuralgia: How patient evaluations of benefits and risks affect the utility of treatment decisions. Pain 131(3): 302-310, 2007

9. $\mathrm{Xu} \mathrm{SJ}, \mathrm{Chen} \mathrm{T}, \mathrm{Wu} \mathrm{CY}$, et al: Percutaneous radiofrequency thermocoagulation for the treatment of trigeminal neuralgia assisted by navigation. Chin J of Neurosurg 21(7):443-444, 2005

10. $X u$ LS, Wei $X Z$, Zhang $X$, et al: Analysis of the causes of failure of percutaneous retrogasserian neurolysis with glycerol for primary trigeminal neuralgia. Chin J Clin Neurosurg 10(5):331-333, 2005

11. Xu LS, Wei XZ, Zhang X, et al: Experimental study of retrogasserian glycerol rhizotomy for trigeminal neuralgia in rats. Acta Academiae Medicinae Militaris Tertiae 27(8):737-739, 2005

12. Zou YW, Xu MH, Chen GX, et al: Result of percutaneous retrogasserian glycerol rhizotomy for trigeminal neuralgia. Chin J Pain Med 4(2):116-119, 1998 